\title{
Large-scale forest inventories of the United States and China reveal positive effects of biodiversity on productivity
}

\author{
James V Watson ${ }^{1}$, Jingjing Liang ${ }^{1 *}$, Patrick C Tobin ${ }^{2,3}$, Xiangdong Lei $^{4}$, James S Rentch ${ }^{1}$ and Catherine E Artis ${ }^{1}$
}

\begin{abstract}
Background: With the loss of species worldwide due to anthropogenic factors, especially in forested ecosystems, it has become more urgent than ever to understand the biodiversity-ecosystem functioning relationship (BEFR). BEFR research in forested ecosystems is very limited and thus studies that incorporate greater geographic coverage and structural complexity are needed.
\end{abstract}

Methods: We compiled ground-measured data from approx. one half million forest inventory sample plots across the contiguous United States, Alaska, and northeastern China to map tree species richness, forest stocking, and productivity at a continental scale. Based on these data, we investigated the relationship between forest productivity and tree species diversity, using a multiple regression analysis and a non-parametric approach to account for spatial autocorrelation.

Results: In general, forests in the eastern United States consisted of more tree species than any other regions in the country. The highest forest stocking values over the entire study area were concentrated in the western United States and Central Appalachia. Overall, $96.4 \%$ of sample plots $(477,281)$ showed a significant positive effect of species richness on site productivity, and only $3.6 \%(17,349)$ had an insignificant or negative effect.

Conclusions: The large number of ground-measured plots, as well as the magnitude of geographic scale, rendered overwhelming evidence in support of a positive BEFR. This empirical evidence provides insights to forest management and biological conservation across different types of forested ecosystems. Forest timber productivity may be impaired by the loss of species in forests, and biological conservation, due to its potential benefits on maintaining species richness and productivity, can have profound impacts on the functioning and services of forested ecosystems.

Keywords: Tree species diversity; Forest management; Biological conservation; Continental map of forest diversity; Spatial autocorrelation; Bootstrap

\section{Background}

Over the past two decades, there has been an extensive discussion (see Cardinale et al. 2012; Naeem et al. 2012 and references therein) over the biodiversity-ecosystem functioning relationship (BEFR). The loss of biodiversity can greatly alter the characteristics and functioning of an ecosystem, including its productivity (Liang et al. 2015) and services (Hooper et al. 2005). With the loss of species worldwide due to anthropogenic factors, climatic disturbance, altered disturbance regimes, and biological invasions, etc. (Fleming et al. 2011), it has

\footnotetext{
* Correspondence: alpenbering@gmail.com

1 Davis College of Agriculture, Natural Resources and Design, West Virginia University, 26506 Morgantown, WV, USA

Full list of author information is available at the end of the article
}

become more urgent than ever to understand the BEFR (Symstad et al. 2003).

There is increasing evidence that supports a positive BEFR, which indicates the loss of biodiversity affects the functioning of an ecosystem (Loreau et al. 2001; Hooper et al. 2005; Cardinale et al. 2012; Naeem et al. 2012; Liang et al. 2015). There are several mechanisms which are thought to be the basis for a positive BEFR. Historically, it is thought that niche complementarity (Loreau et al. 2001; Cardinale et al. 2011; Reich et al. 2012), which constitutes niche differentiation and species facilitation, as well as the sampling effects (Hooper and Vitousek 1997; Wardle 1999), i.e., the chance that a forest contains a more productive species increases with increasing species diversity, 
are reasons for a positive BEFR. Recently, Liang et al. (2015) developed a theoretical model to integrate complementarity and a new mechanism of diminishing marginal productivity in quantifying the effects of biodiversity loss on plant productivity.

Most existing evidence of a positive BEFR comes from grassland experiments at limited spatial scales (Loreau et al. 2001; Symstad et al. 2003; Cardinale et al. 2012). Since these experiments usually do not include some key processes inherent to natural ecosystems, such as the introduction of new species, decomposition of woody plant material, large standing crop, and the utilization of water by woody tree species, it is difficult to extrapolate the results to greater temporal and spatial scales (Symstad et al. 2003).

BEFR studies in forested ecosystems are in general limited to empirical analysis of observed data (Liang et al. 2007, 2015; Paquette and Messier 2011; Zhang et al. 2012), primarily due to the complexity of forested ecosystems and the length of time it takes to derive estimates of growth and productivity. Although some argue otherwise (Chen et al. 2003; Vilà et al. 2003), the majority of studies confirm a positive relationship between tree diversity and ecosystem productivity and services (Kelty 1989; Caspersen and Pacala 2001; Liang et al. 2005, 2007, 2015; Lei et al. 2009b; Paquette and Messier 2011; Young et al. 2011; Zhang et al. 2012; Gamfeldt et al. 2013). BEFR also plays an important role in the management of forest resources. A traditional view in silviculture is that clearcutting with artificial regeneration (even-aged monoculture) optimizes forest productivity (e.g., Assmann 1970), but it has been found that this maxim does not generalize (Hasse and Ek 1981; Haight and Monserud 1990) and that the mixed-species stands could have higher long-term productivity (e.g., Haight and Monserud 1990; Buongiorno et al. 1995; Liang et al. 2005, 2006). Most biodiversity studies in forested ecosystems have primarily used even-aged designs that lack structure complexity of natural uneven-aged forests (Leuschner et al. 2009). Thus, studies that incorporate greater geographic coverage and structural complexity are much needed for analyzing the BEFR in forested ecosystems.

Biodiversity studies of forested ecosystems, especially at larger geographic scales, are not only of great value to BEFR research, but also of strategic importance to the world's energy security and economic development. Tree species provide an essential source of energy and financial income worldwide, especially for rural areas where livelihoods depend heavily on forest resources (FAO 2012). The limited maps of biodiversity across the world's forested ecosystems were developed using either raster data or point data. Biodiversity maps of raster data (Ricketts 1999; Hernandez-Stefanoni and Ponce-Hernandez 2006; Hernández-Stefanoni and Dupuy 2007; Kreft and Jetz 2007; Liang 2012) are mostly based on a combination of ground measurements, remote sensing data, and spatial estimation. As variance is ignored within a raster, such maps have limited value to BEFR studies. Maps showing distribution of biodiversity, consisting of point data are the most valuable, because spatially explicit biodiversity records can be matched with the forest productivity data at the same locations for the study of BEFR. Unfortunately, due to the cost of ground measurements, largescale maps of forest biodiversity are extremely limited across the world (Köble and Seufert 2001) and to the best of our knowledge, there is no map of forest biodiversity at the national scale for the United States.

The primary objective of this study was to investigate the effects of biodiversity on forest timber productivity, using extensive forest inventory data from the United States of America and China. The secondary objective was to synthesize these ground-measured data in mapping tree species richness, forest stocking, and productivity over all types of temperate forests across the United States.

\section{Methods \\ Data}

Data for this study came from two sources- Forest Inventory and Analysis of the United States of America (FIA, see Woudenberg et al. 2011) and the Forest Management Planning Inventory (FMPI) from the Wangqing Forestry Bureau in the Jilin Province of China (He et al. 2013).

\section{FIA}

The FIA databases are a product of the United States Department of Agriculture (USDA), Forest Service FIA Program, which has established a network of permanent sample plots across the United States to determine the extent and status of the nation's forests in regard to the condition, volume, growth, and depletions (Woudenberg et al. 2011). The FIA ground-based inventories have been conducted at different time periods by states, ranging from the 1960s to 2012. Following the passage of the 1998 Farm Bill (Gillespie 1999), the FIA program in the new millennium switched from a periodic inventory system to an annual system in which a portion of the FIA plots in each state would be remeasured each year (Gillespie 1999).

The FIA program uses a 3-phase sampling scheme (Woudenberg et al. 2011). Phase 1 uses stratification to aggregate ground samples into groups to minimize variance using stratified estimation. Every FIA ground plot is assigned to a stratum of which a weight is based on its proportion within the estimation unit. Phase 2 consists of actual FIA ground plots, which follow a national standard and are fixed-radius plots 0.40 ha in size. To protect the privacy of landowners, geographic coordinates of FIA ground plots are "fuzzed" (Lister et al. 2002). The true plot locations are known to be within $1.61 \mathrm{~km}$ of the fuzzed values under the periodic system, and $0.80 \mathrm{~km}$ under the 
current plot design that was first used in the 1990s for the last of the periodic inventories and all of the current annual inventories (Woudenberg et al. 2011). The ramifications of using the fuzzed coordinates instead of real ones are provided in the discussion.

In the current FIA plot design, each permanent sample plot consists of four 0.02-ha subplots $7.32 \mathrm{~m}$ in radius. Subplots 2, 3, and 4 are situated around subplot 1 in a triangular pattern, with a $36.58-\mathrm{m}$ distance between the plot centers of subplots 2, 3, and 4 and the center of subplot 1 (Bechtold and Scott 2005). On a subplot, all trees greater than or equal to $12.70 \mathrm{~cm}$ in diameter at breast height (dbh) are measured. A 2.07-m radius microplot is located inside of each of the 4 subplots, in which all trees with a dbh smaller than $12.70 \mathrm{~cm}$ are tagged and measured.

FIA inventories are designed in a way such that state level sampling errors are met at the $67 \%$ confidence limit (Woudenberg et al. 2011). Sampling error is kept $\leq 3 \%$ for every 404,686 ha of timberland. It should be noted that despite the mandated sampling error to the area, the sampling errors applied to removals, volume, and total annual growth are targeted by the FIA program, which is $5 \%$ for every $3 \times 10^{7} \mathrm{~m}^{3}$ of growing stock on timberland for the eastern United States and $10 \%$ for every $3 \times 10^{7} \mathrm{~m}^{3}$ for the western United States. A total of 475,892 FIA permanent sample plots distributed across the contiguous United States and Alaska (Fig. 1) were used in this study.

\section{FMPI}

The FMPI data were collected from permanent sample plots at the forest management unit (FMU) level in the Wangqing Forestry Bureau $\left(43^{\circ} 05^{\prime}-43^{\circ} 40^{\prime} \mathrm{N}, 1^{\circ} 56^{\prime}-\right.$ $131^{\circ} 04^{\prime}$ E) of China in 2007 (He et al. 2013). The study area is situated on the middle lower hill region of the Changbai Mountains in northeastern China. Elevation ranges from 550 to $1,100 \mathrm{~m}$ A.S.L. with an annual rainfall of $547 \mathrm{~mm}$. The mean annual temperature is $3.9{ }^{\circ} \mathrm{C}$. Mean monthly maximum and minimum temperatures range between $22{ }^{\circ} \mathrm{C}$ and $-37.5{ }^{\circ} \mathrm{C}$, respectively. The study area was originally dominated by the mixed broad-leaved Korean pine (Pinus koraiensis) forest type, with dark brown forest soil. Most primary forests, however, have been altered into other forest types such as spruce-fir dominated mixed coniferous forests, birch-aspen mixed broadleaved forests, or plantations consisting of larch, spruce, fir, and pine after forestry practices and other disturbances.

The purpose of FMPI is to assess forest resources and to supply information requirements for forest management planning, spatial and functional patterns, and overall design of forestry at the FMU level (Lei et al. 2009a). Sample plots, systematically designed with a $1 \mathrm{~km} \times$ $2 \mathrm{~km}$ grid, were measured with a 10-year interval. In total there are 1,389 plots distributed in the forest bureau (Fig. 2). The $0.06-\mathrm{km}^{2}$ plot is rectangular. In each plot, species and diameter of trees with a dbh above $5 \mathrm{~cm}$ were recorded. Three to five average trees were selected to measure age and height for computing stand age and height. Other factors measured are slope, aspect, elevation, soil type, soil depth, and management history.

\section{Forest mapping}

To study the forest productivity, stocking, and species diversity across the United States, state and regional FIA databases, obtained from different FIA regional offices, were compiled together into one nationwide master database (hereafter, master database). Using SQL queries

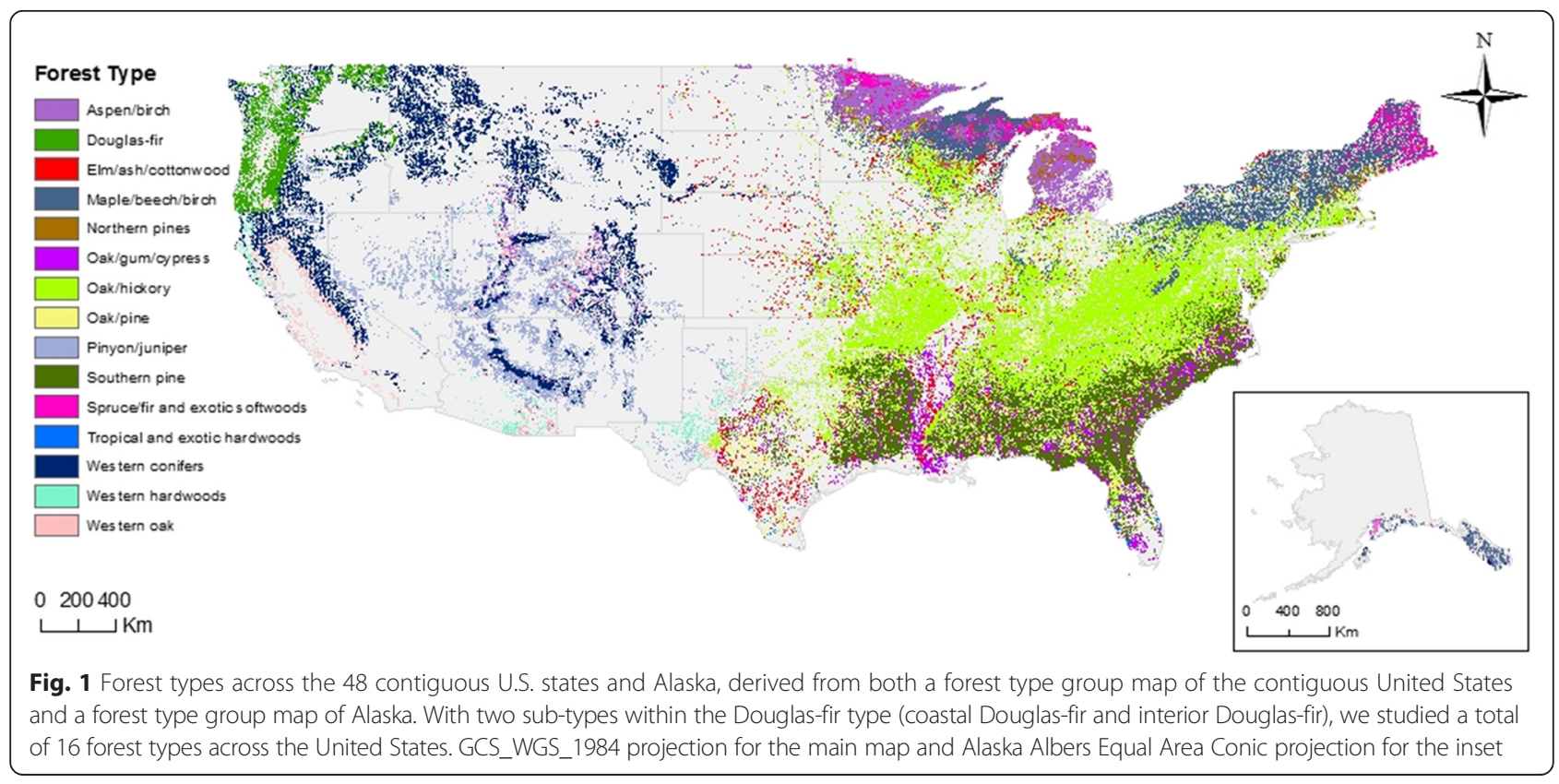




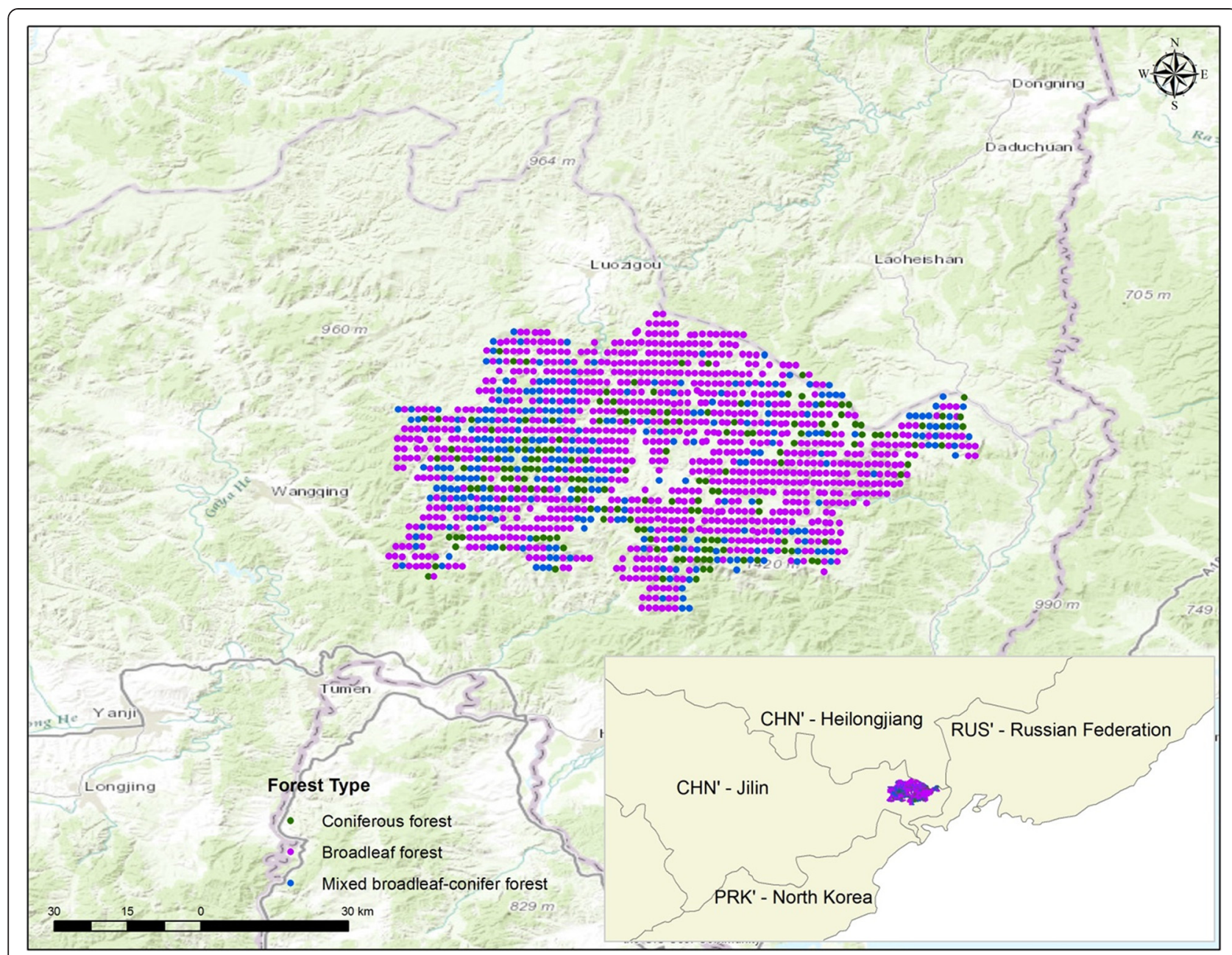

Fig. 2 Geographic distribution of the 1,389 FMPI plots in Northeastern China

of the Microsoft Access program, we first extracted values of $12 \mathrm{key}$ attributes from individual state and regional FIA databases - plot number, tree species, dbh, tree status, trees per unit area that a sample tree represents, elevation, slope, forest type, site productivity class, latitude, longitude, and inventory year. The key attributes, which were used to develop the seven final variables used in this study (Table 1), were all directly measured in the field, with an exception of forest type, which was assigned based on the plot location and the forest type map across the contiguous United States and Alaska at a 250-m spatial resolution (Ruefenacht et al. 2008). We only selected these 12 key attributes for the master database because 1) these attributes are essential for deriving forest productivity, basal area, and tree species diversity that were used in our study; 2) all individual state and regional databases have these attributes; and 3) all the redundant or unused attributes from individual databases were deleted to keep the master database within our computation and storage capacity. After removing inconsistent, missing, and apparently erroneous entries, the final master database consisted of 475,892 permanent sample plots distributed across the contiguous United States and Alaska.

Tree species diversity $(N)$, in terms of species richness, was derived from the predesignated numeric codes named "SPCD" that identifies species of every single tree in the FIA databases (Woudenberg et al. 2011). $N$ represents the number of species among all the live trees on a permanent sample plot and across the United States, and ranges from 1 to 24 (Table 2).

Basal area $(B)$, the total cross sectional area of all the live trees on a permanent sample plot, was derived from the FIA attributes dbh, tree status (ST), and trees per unit area (TPA) that a sample tree represents according to:

$$
B=\frac{\sum 3.14 \cdot \mathrm{dbh}_{\mathrm{ST}=1}^{2} \cdot \mathrm{TPA}}{4}
$$

where tree status is a field recorded code defining the status of a tree: 0 indicates no status, 1 live, 2 dead, and 
Table 1 Definition and units for variables used in this study

\begin{tabular}{|c|c|c|c|}
\hline Variable & Units & Short definition & Long definition \\
\hline $\bar{C}$ & $\mathrm{~m}^{3} \cdot \mathrm{ha}^{-1} \cdot \mathrm{yr}^{-1}$ & Site productivity & $\begin{array}{l}\text { A measure of the potential timber growth } \\
\text { that the site is capable of producing. It is } \\
\text { based on the average annual increment } \\
\text { of naturally occurring, fully stocked stands. }\end{array}$ \\
\hline B & $m^{2} \cdot h a^{-1}$ & Stand basal area & $\begin{array}{l}\text { Total stand basal area of all the living } \\
\text { trees from the most current measurement } \\
\text { in FIA data. }\end{array}$ \\
\hline E & $\mathrm{m}$ & Plot elevation & $\begin{array}{l}\text { The vertical distance that a plot is located } \\
\text { from sea level. Positive values indicate } \\
\text { that the plot is located above sea level } \\
\text { while negative values indicate that the } \\
\text { plot was located below sea level. } 70 \% \\
\text { of the values were obtained from the } \\
\text { DEM of the United States and } 30 \% \\
\text { from ground measurement. }\end{array}$ \\
\hline S & degrees & Slope & $\begin{array}{l}\text { The angle of slope in degrees; } 5.6 \% \text { of } \\
\text { the values were obtained from the DEM } \\
\text { of the United States and } 94.4 \% \text { from } \\
\text { ground measurement. }\end{array}$ \\
\hline N & & Species richness & $\begin{array}{l}\text { The total number of different species of } \\
\text { woody trees present on the plot. }\end{array}$ \\
\hline y & degrees & Latitude & Latitude of the plot in NAD 83 \\
\hline$x$ & degrees & Longitude & Longitude of the plot in NAD 83 \\
\hline
\end{tabular}

3 indicates a tree that has been removed (Woudenberg et al. 2011). Over the contiguous United States and Alaska, $B$ ranges from 0 to $279.19 \mathrm{~m}^{2} \cdot \mathrm{ha}^{-1}$ (Table 2).

The data for elevation $(E)$ and slope $(S)$, which were only used to develop a continuous measure of site productivity based on site class (see Eq. 2 below), were mostly obtained from the ground-measured FIA databases. However, $70 \%$ of FIA plots in the master database were missing elevation records and $5.6 \%$ were missing slope records. To retain these plots for the estimation of site productivity, especially for those forest types with a relatively small sample size (e.g., tropical and exotic hardwoods have only 408 plots and western hardwoods 1,924 plots), we derived the missing data from the plot coordinates and the Digital Elevation Model (DEM) of the United States. For the elevation, $70 \%$ of data were derived from the DEM of the United States, and $30 \%$ from the FIA databases. For the slope, $5.6 \%$ of data came from the United States DEM and $94.4 \%$ from the FIA databases. The DEM of the contiguous United States (30-m resolution) and Alaska (60-m resolution) was downloaded from the Geospatial Data Gateway site (http://datagateway.nrcs.usda.gov/, last accessed December 18, 2014).

The forest type map across the contiguous United States and Alaska was developed by Ruefenacht et al. (2008) based on the FIA data. The map has a 250-m spatial resolution, with an accuracy of $\approx 69 \%$ for the 48 contiguous U.S. states, and $\approx 78 \%$ for Alaska. For simplicity, in this study, we grouped some of the original forest types together based on similar geographic location and species composition to reduce the total number of forest types from 30 to 15 (Fig. 1).

Only one of the 15 forest types was divided into subtypes. The Douglas-fir forest type consisted of Douglas-fir forests which grow near the Pacific coast and Douglas-fir forests which grow much further inland. Because of substantial differences in the climate and other growing conditions (Hermann and Lavender 1990), the Douglas-fir forest type was separated into two subtypes, the coastal Douglas-fir forests (west of the longitude $120^{\circ} \mathrm{W}$ ) and the inland Douglas-fir forests (east of the longitude $120^{\circ} \mathrm{W}$ ). The coastal Douglas-fir forests mainly consist of coast Douglas-fir (Pseudotsuga menziesii var. menziesii), whereas the inland Douglas-fir forests are comprised mostly of another variety of Douglas-fir, namely Rocky Mountain or interior Douglas-fir (P. menziesii var. glauca).

Site productivity $(C)$, a measure of the potential timber growth that a plot is capable of sustaining, was derived from a categorical attribute from the FIA databases named "SITECLCD" which ranks site productivity in a hierarchical order from one to seven. Each code of SITECLCD denotes a range of productivity: 1 stands for the most productive sites with a mean annual increment (MAI, see Hanson et al. 2003) greater than or equal to $15.74 \mathrm{~m}^{3} \cdot \mathrm{ha}^{-1} \cdot \mathrm{yr}^{-1} ; 2$ for $11.55-15.74 \mathrm{~m}^{3} \cdot \mathrm{ha}^{-1} \cdot \mathrm{yr}^{-1} ; 3$ for $8.40-11.55 \mathrm{~m}^{3} \cdot \mathrm{ha}^{-1} \cdot \mathrm{yr}^{-1}$; 4 for $5.95-8.40 \mathrm{~m}^{3} \cdot \mathrm{ha}^{-1}$. $\mathrm{yr}^{-1}$; 5 for $3.50-5.95 \mathrm{~m}^{3} \cdot \mathrm{ha}^{-1} \cdot \mathrm{yr}^{-1}$; 6 for $1.40-3.50 \mathrm{~m}^{3}$. $\mathrm{ha}^{-1} \cdot \mathrm{yr}^{-1}$, and 7 for the least productive sites with a MAI less than $1.40 \mathrm{~m}^{3} \cdot \mathrm{ha}^{-1} \cdot \mathrm{yr}^{-1}$ (Woudenberg et al. 2011). We converted the categorical attribute of SITECLCD 
Table 2 Summary statistics by forest type. Std: Standard Deviation, n: total number of plots

\begin{tabular}{|c|c|c|c|c|c|c|c|}
\hline & $\begin{array}{l}\text { Productivity } \\
\left(\mathrm{m}^{3} \cdot \mathrm{ha}^{-1} \cdot \mathrm{yr}^{-1}\right)\end{array}$ & Number of Species & $\begin{array}{l}\text { Basal area } \\
\left(\mathrm{m}^{2} \cdot \mathrm{ha}^{-1}\right)\end{array}$ & Elevation (km) & $\begin{array}{l}\text { Slope } \\
\text { (degrees) }\end{array}$ & $\begin{array}{l}\text { Latitude } \\
\text { (degrees) }\end{array}$ & $\begin{array}{l}\text { Longitude } \\
\text { (degrees) }\end{array}$ \\
\hline \multicolumn{8}{|c|}{ National (all forest types combined) } \\
\hline Mean & 4.84 & 6.00 & 19.13 & 0.61 & 6.29 & 38.20 & -88.67 \\
\hline Std. & 2.76 & 3.42 & 11.96 & 0.73 & 8.09 & 5.71 & 11.02 \\
\hline Max. & 15.03 & 24.00 & 279.19 & 3.92 & 60.24 & 61.46 & -67.00 \\
\hline Min. & -0.50 & 1.00 & 0 & -0.08 & 0 & 24.63 & -153.86 \\
\hline$n$ & 475,892 & 475,892 & 475,892 & 475,892 & 475,892 & 475,892 & 475,892 \\
\hline \multicolumn{8}{|c|}{ Pinyon/juniper } \\
\hline Mean & 0 & 2.21 & 17.68 & 1.84 & 11.33 & 37.06 & -110.00 \\
\hline Std. & 1.27 & 1.41 & 13.27 & 0.51 & 9.72 & 2.84 & 5.56 \\
\hline Max. & 12.41 & 19.00 & 130.34 & 3.35 & 57.17 & 48.14 & -71.90 \\
\hline Min. & -0.50 & 1.00 & 0 & -0.07 & 0.00 & 29.27 & -122.78 \\
\hline$n$ & 16,709 & 16,709 & 16,709 & 16,709 & 16,709 & 16,709 & 16,709 \\
\hline \multicolumn{8}{|c|}{ Douglas-fir (Coastal) } \\
\hline Mean & 8.43 & 4.24 & 23.53 & 0.18 & 5.63 & 45.23 & -122.53 \\
\hline Std. & 3.48 & 2.08 & 27.03 & 0.22 & 10.03 & 1.88 & 1.01 \\
\hline Max. & 14.97 & 13.00 & 188.99 & 1.52 & 44.71 & 48.99 & -120.00 \\
\hline Min. & -0.48 & 1.00 & 0 & 0 & 0 & 42.00 & -124.68 \\
\hline$n$ & 5,866 & 5,866 & 5,866 & 5,866 & 5,866 & 5,866 & 5,866 \\
\hline \multicolumn{8}{|c|}{ Douglas-fir (Interior) } \\
\hline Mean & 4.41 & 3.70 & 10.10 & 0.16 & 3.54 & 47.50 & -118.26 \\
\hline Std. & 2.35 & 2.00 & 9.05 & 0.23 & 7.74 & 1.57 & 0.83 \\
\hline Max. & 12.39 & 12.00 & 58.71 & 1.77 & 43.38 & 48.99 & -116.56 \\
\hline Min. & -0.48 & 1.00 & 0 & 0.01 & 0 & 43.92 & -119.99 \\
\hline$n$ & 1,211 & 1,211 & 1,211 & 1,211 & 1,211 & 1,211 & 1,211 \\
\hline \multicolumn{8}{|c|}{ Oak/pine } \\
\hline Mean & 5.61 & 6.65 & 17.60 & 0.52 & 4.50 & 33.49 & -85.83 \\
\hline Std. & 2.59 & 3.54 & 10.71 & 0.67 & 6.27 & 2.79 & 6.05 \\
\hline Max. & 15.01 & 22.00 & 80.46 & 3.65 & 60.24 & 47.97 & -68.82 \\
\hline Min. & -0.48 & 1.00 & 0 & -0.04 & 0 & 26.26 & -103.00 \\
\hline$n$ & 19,023 & 19,023 & 19,023 & 19,023 & 19,023 & 19,023 & 19,023 \\
\hline \multicolumn{8}{|c|}{ Oak/gum/cypress } \\
\hline Mean & 5.91 & 6.23 & 20.59 & 0.53 & 1.53 & 32.29 & -84.95 \\
\hline Std. & 2.56 & 3.39 & 13.72 & 0.70 & 3.38 & 2.23 & 5.47 \\
\hline Max. & 15.03 & 22.00 & 136.46 & 3.80 & 57.17 & 42.60 & -71.40 \\
\hline Min. & -0.47 & 1.00 & 0 & 0 & 0 & 24.63 & -101.37 \\
\hline$n$ & 28,431 & 28,431 & 28,431 & 28,431 & 28,431 & 28,431 & 28,431 \\
\hline
\end{tabular}


Table 2 Summary statistics by forest type. Std: Standard Deviation, n: total number of plots (Continued)

\begin{tabular}{|c|c|c|c|c|c|c|c|}
\hline & $\begin{array}{l}\text { Productivity } \\
\left(\mathrm{m}^{3} \cdot \mathrm{ha}^{-1} \cdot \mathrm{yr}^{-1}\right)\end{array}$ & Number of Species & $\begin{array}{l}\text { Basal area } \\
\left(\mathrm{m}^{2} \cdot \mathrm{ha}^{-1}\right)\end{array}$ & Elevation (km) & $\begin{array}{l}\text { Slope } \\
\text { (degrees) }\end{array}$ & $\begin{array}{l}\text { Latitude } \\
\text { (degrees) }\end{array}$ & $\begin{array}{l}\text { Longitude } \\
\text { (degrees) }\end{array}$ \\
\hline \multicolumn{8}{|c|}{ Elm/ash/cottonwood } \\
\hline Mean & 4.75 & 5.52 & 16.87 & 0.45 & 3.60 & 38.30 & -91.30 \\
\hline Std. & 3.15 & 3.27 & 11.04 & 0.57 & 6.17 & 5.37 & 6.55 \\
\hline Max. & 15.03 & 22.00 & 130.62 & 3.61 & 43.53 & 61.44 & -67.17 \\
\hline Min. & -0.47 & 1.00 & 0 & 0 & 0 & 26.13 & -153.46 \\
\hline$n$ & 11,742 & 11,742 & 11,742 & 11,742 & 11,742 & 11,742 & 11,742 \\
\hline \multicolumn{8}{|c|}{ Aspen/birch } \\
\hline Mean & 4.77 & 18.42 & 0.60 & 4.19 & 45.76 & -90.76 & -90.76 \\
\hline Std. & 2.32 & 10.53 & 0.72 & 5.34 & 2.30 & 6.43 & 6.43 \\
\hline Max. & 14.97 & 16.00 & 95.88 & 3.68 & 56.49 & 61.42 & -67.23 \\
\hline Min. & -0.49 & 1.00 & 0 & 0 & 0 & 33.62 & -151.73 \\
\hline$n$ & 46,411 & 46,411 & 46,411 & 46,411 & 46,411 & 46,411 & 46,411 \\
\hline \multicolumn{8}{|c|}{ Southern pine } \\
\hline Mean & 5.97 & 5.87 & 17.61 & 0.53 & 2.89 & 32.65 & -85.06 \\
\hline Std. & 2.46 & 3.45 & 11.47 & 0.68 & 4.49 & 2.07 & 5.46 \\
\hline Max. & 15.02 & 23.00 & 140.89 & 3.86 & 57.17 & 44.00 & -70.00 \\
\hline Min. & -0.47 & 1.00 & 0 & -0.08 & 0 & 25.76 & -101.23 \\
\hline$n$ & 102,844 & 102,844 & 102,844 & 102,844 & 102,844 & 102,844 & 102,844 \\
\hline \multicolumn{8}{|c|}{ Oak/hickory } \\
\hline Mean & 4.97 & 7.77 & 18.86 & 0.45 & 9.38 & 37.15 & -85.40 \\
\hline Std. & 2.47 & 3.45 & 9.82 & 0.58 & 9.07 & 3.18 & 5.80 \\
\hline Max. & 15.02 & 24.00 & 87.62 & 3.92 & 57.17 & 48.99 & -68.75 \\
\hline Min. & -0.48 & 1.00 & 0 & -0.03 & 0 & 25.61 & -104.38 \\
\hline$n$ & 141,062 & 141,062 & 141,062 & 141,062 & 141,062 & 141,062 & 141,062 \\
\hline \multicolumn{8}{|c|}{ Maple/beech/birch } \\
\hline Mean & 4.03 & 6.22 & 21.85 & 0.44 & 5.88 & 44.16 & -82.11 \\
\hline Std. & 2.15 & 2.57 & 10.89 & 0.47 & 6.68 & 2.28 & 8.45 \\
\hline Max. & 14.97 & 20.00 & 80.58 & 3.71 & 57.00 & 49.00 & -67.11 \\
\hline Min. & -0.47 & 1.00 & 0 & 0 & 0 & 34.81 & -102.82 \\
\hline$n$ & 47,350 & 47,350 & 47,350 & 47,350 & 47,350 & 47,350 & 47,350 \\
\hline \multicolumn{8}{|c|}{ Tropical and exotic hardwoods } \\
\hline Mean & 3.82 & 3.14 & 14.72 & 0.54 & 0.95 & 28.44 & -86.44 \\
\hline Std. & 2.79 & 2.52 & 13.72 & 0.64 & 3.10 & 1.74 & 7.14 \\
\hline Max. & 12.45 & 13.00 & 60.24 & 3.56 & 34.33 & 35.32 & -80.11 \\
\hline Min. & -0.46 & 1.00 & 0 & 0 & 0 & 25.79 & -120.48 \\
\hline$n$ & 408 & 408 & 408 & 408 & 408 & 408 & 408 \\
\hline
\end{tabular}


Table 2 Summary statistics by forest type. Std: Standard Deviation, n: total number of plots (Continued)

\begin{tabular}{|c|c|c|c|c|c|c|c|}
\hline & $\begin{array}{l}\text { Productivity } \\
\left(\mathrm{m}^{3} \cdot \mathrm{ha}^{-1} \cdot \mathrm{yr}^{-1}\right)\end{array}$ & $\begin{array}{l}\text { Number of } \\
\text { Species }\end{array}$ & $\begin{array}{l}\text { Basal area } \\
\left(\mathrm{m}^{2} \cdot h a^{-1}\right)\end{array}$ & Elevation (km) & $\begin{array}{l}\text { Slope } \\
\text { (degrees) }\end{array}$ & $\begin{array}{l}\text { Latitude } \\
\text { (degrees) }\end{array}$ & $\begin{array}{l}\text { Longitude } \\
\text { (degrees) }\end{array}$ \\
\hline \multicolumn{8}{|c|}{ Spruce/fir and exotic softwoods } \\
\hline Mean & 3.59 & 4.79 & 20.33 & 0.48 & 2.73 & 46.54 & -85.49 \\
\hline Std. & 2.06 & 2.34 & 11.99 & 0.56 & 4.09 & 1.49 & 10.11 \\
\hline Max. & 14.96 & 15.00 & 80.86 & 3.68 & 56.49 & 61.46 & -67.00 \\
\hline Min. & -0.46 & 1.00 & 0 & 0 & 0 & 38.28 & -151.73 \\
\hline$n$ & 18,761 & 18,761 & 18,761 & 18,761 & 18,761 & 18,761 & 18,761 \\
\hline \multicolumn{8}{|c|}{ Northern pines } \\
\hline Mean & 4.38 & 4.69 & 19.75 & 0.44 & 3.87 & 44.82 & -85.23 \\
\hline Std. & 2.30 & 2.49 & 11.46 & 0.53 & 5.34 & 2.06 & 6.75 \\
\hline Max. & 14.97 & 15.00 & 82.54 & 3.57 & 41.99 & 49.31 & -67.58 \\
\hline Min. & -0.45 & 1.00 & 0 & 0 & 0 & 26.33 & -96.12 \\
\hline$n$ & 9,151 & 9,151 & 9,151 & 9,151 & 9,151 & 9,151 & 9,151 \\
\hline \multicolumn{8}{|c|}{ Western conifers } \\
\hline Mean & 3.80 & 2.75 & 24.55 & 1.86 & 15.54 & 43.00 & -113.93 \\
\hline Std. & 2.93 & 1.43 & 17.66 & 0.78 & 10.57 & 4.58 & 6.88 \\
\hline Max. & 15.00 & 10.00 & 279.19 & 3.70 & 57.17 & 61.11 & -95.06 \\
\hline Min. & -0.50 & 1.00 & 0 & 0 & 0.00 & 31.80 & -153.86 \\
\hline$n$ & 21,792 & 21,792 & 21,792 & 21,792 & 21,792 & 21,792 & 21,792 \\
\hline \multicolumn{8}{|c|}{ Western hardwoods } \\
\hline Mean & 2.61 & 2.08 & 15.70 & 0.94 & 10.56 & 36.87 & -112.68 \\
\hline Std. & 4.65 & 1.46 & 19.66 & 0.76 & 12.26 & 5.57 & 8.39 \\
\hline Max. & 14.99 & 8.00 & 184.50 & 3.17 & 47.73 & 49.00 & -99.21 \\
\hline Min. & -0.48 & 1.00 & 0 & -0.03 & 0 & 29.05 & -124.60 \\
\hline$n$ & 1,924 & 1,924 & 1,924 & 1,924 & 1,924 & 1,924 & 1,924 \\
\hline \multicolumn{8}{|c|}{ Western oak } \\
\hline Mean & 1.23 & 2.35 & 14.38 & 1.34 & 16.87 & 36.79 & -113.99 \\
\hline Std. & 3.13 & 1.37 & 13.21 & 0.80 & 11.71 & 3.29 & 7.14 \\
\hline Max. & 14.97 & 10.00 & 138.16 & 3.12 & 57.17 & 47.47 & -98.46 \\
\hline Min. & -0.49 & 1.00 & 0 & 0 & 0 & 29.57 & -124.20 \\
\hline$n$ & 3,207 & 3,207 & 3,207 & 3,207 & 3,207 & 3,207 & 3,207 \\
\hline \multicolumn{8}{|c|}{ Chinese northeastern temperate forest } \\
\hline Mean & 3.06 & 6.86 & 23.07 & 0.76 & 10.67 & 43.38 & 130.45 \\
\hline Std. & 1.39 & 2.53 & 9.90 & 0.23 & 7.70 & 0.12 & 0.25 \\
\hline Max. & 15.30 & 13.00 & 75.28 & 7.70 & 36.00 & 43.65 & 131.05 \\
\hline Min. & 0.08 & 1.00 & 0 & 0 & 0 & 43.11 & 129.97 \\
\hline$n$ & 1,385 & 1,385 & 1,385 & 1,385 & 1,385 & 1,385 & 1,385 \\
\hline
\end{tabular}

to a continuous attribute of site productivity $(C)$ by accounting for the effects of elevation and slope with a linear model:

$$
C=\alpha_{0}+\alpha_{1} \cdot S I T E C L C D+\alpha_{2} \cdot E+\alpha_{3} \cdot S
$$

where $\alpha_{0}$ through $\alpha_{3}$ were coefficients to be estimated by ordinary least squares (Table 3 ). This model was based on previous findings that elevation and slope both have a profound impact on the productivity of forest sites (Stage and Salas 2007 and references therein). The model was calibrated with FIA data from the entire country by fitting observed plot-level values of SITECLCD, E, and $S$ against the mid-point MAI values of the SITECLCD. The model was examined for the level of significance of the coefficients, the biological interpretation, and the normality 
Table 3 Parameters of the site productivity model

\begin{tabular}{lllll}
\hline & \multicolumn{2}{l}{ Independent variables } & Constant \\
\cline { 2 - 4 } & SITECLCD & $E$ & $S$ & \\
\hline Coef. & -2.442 & 0.082 & 0.002 & 16.960 \\
SE & 0.000 & 0.001 & 0.000 & 0.002 \\
$P$ & $<0.0001$ & $<0.0001$ & $<0.0001$ & $<0.0001$ \\
$R^{2}$ & 0.98 & & & \\
$\mathrm{dF}$ & 475,888 & & & \\
\hline
\end{tabular}

of residual pattern. Then, we estimated the actual site productivity of 475,892 FIA plots using the values of SITECLCD, $E$, and $S$ in Eq. 2, thereby making the site productivity of FIA plots a continuous variable across the country.

The master database was created to produce nationwide maps of forest stocking (basal area), tree species richness, and site productivity. For the creation of each of these maps, two separate data layers were developed; one for Alaska and one for the contiguous United States. Each plot represents a raster with size $0.05^{\circ}$ for the contiguous United States and size $0.2^{\circ}$ for Alaska. The GCSWGS-1984 projection was used for the contiguous United States and the Alaska Albers Equal Area Conic projection (NAD_1983 datum) was used for Alaska.

\section{Diversity-productivity relationship}

For each of the 15 forest types across the contiguous United States and Alaska, a multiple regression analysis was conducted to test the general effect of tree species richness $(N)$ on site productivity $(C)$, with forest stocking $(B)$ being accounted for:

$$
\begin{aligned}
C_{i j}= & \beta_{0, i}+\beta_{1, i} \cdot N_{i j}+\beta_{2, i} \cdot N_{i j}^{2}+\beta_{3, i} \cdot N_{i j} \cdot B_{i j} \\
& +\beta_{4, i} \cdot B_{i j}+e_{i j}
\end{aligned}
$$

where $B$ represents forest stocking $\left(\mathrm{m}^{2} \cdot \mathrm{ha}^{-1}\right)$ and $C$ represents site productivity $\left(\mathrm{m}^{3} \cdot \mathrm{ha}^{-1} \cdot \mathrm{yr}^{-1}\right), i$ forest type $(i=1,2,3, \ldots, 15)$, and $j$ permanent sample plot number within the $i$ th forest type. $e$ represents the random error term. Coefficients ( $\beta$ 's) were estimated with ordinary least squares, based on two assumptions: the sample is random, and the error term is of zero conditional mean and homoskedasticity. The full quadratic terms of $N$ and $B$ were incorporated in Eq. 3 to study how site productivity $(C)$ changes in response to changes in species richness $(N)$ while keeping basal area (B) constant at its sample mean for that forest type.

We employed Eq. 3 to study BEFR across different forest types, with an underlying assumption that biotic factors, namely species diversity and basal area, have direct causal effects on forest productivity. This assumption was supported by recent BEFR studies (e.g., Zhang et al. 2012; Liang et al. 2015) in terms of biodiversity effects, and a majority of forest dynamics studies (e.g., Shugart 1984) in terms of basal area effects. It should be noted, however, that we did not consider any abiotic factors in this study except for elevation and slope (Eq. 2) due to a lack of soil and other environmental records. Subject to the potential omitted-variable bias (Wooldridge 2000), our results should be interpreted with caution. For instance, our results may address the effects of biodiversity on productivity, but the abiotic causes of biodiversity variation across the study region and their potential confounding effect on BEFR were not directly detectable with this database. Nevertheless, as an inherent nature of abiotic factors, their potential effects especially on forest productivity are in general spatially autocorrelated (Legendre 1993; Liang 2012). To this end, we also employed a geospatial model to account for spatial autocorrelation and potential effects of abiotic factors.

Due to potential spatial autocorrelation, which can bias tests of significance due to the violation of independence (Clifford et al. 1989) in the FIA data, we measured the spatial autocorrelation function for $C$ for each forest type using a nonparametric approach (Bjørnstad and Falck 2001). Due to computational constraints, it was not possible to estimate the spatial autocorrelation function for most forest type's entire set of data; for example, the maximum number of sample locations for any one forest type was 141,062, while in $75 \%$ of the forest types the number of spatial locations exceeded 7,000 . To overcome this constraint, we used a bootstrapping sampling approach in which, for each forest type, up to $\approx$ 2,000 spatial locations and their associated value of $C$ were randomly selected, from which we estimated parameters of the spatial autocorrelation. This procedure was repeated independently 200 times, from which we estimated the mean, and the $95 \%$ confidence intervals using the $0.025 \%$ and $0.975 \%$ quantiles of the bootstrapped distribution of the parameters (Efron and Tibshirani 1993). Since $C$ for most forest types revealed initially some level of spatial autocorrelation, as determined by $95 \%$ confidence intervals that did not include 0 for the estimate of the local spatial autocorrelation (Bjørnstad and Falck 2001), we sought to detrend the data using a second-order polynomial spatial model fit to values of $C$ for each forest type according to:

$$
C_{x, y}=x+y+x y+x^{2}+y^{2}
$$

in which $x$ and $y$ represent the longitude and latitude, respectively, of the spatial location corresponding to the value of $C$. In this case, we used all values of $C$ for each forest type as opposed to a randomly chosen subset. We used mixed stepwise regression to determine the appropriate model. Ultimately, 13 of the 15 forest types exhibited significant spatial autocorrelation in values of $C$ as ascertained by significance of at least one parameter 
Table 4 Estimates of spatial autocorrelation and the appropriate spatial detrending model for all 15 forest types

\begin{tabular}{|c|c|c|c|c|}
\hline \multirow[t]{2}{*}{ Forest type } & \multicolumn{2}{|l|}{ Spatial autocorrelation estimates } & \multicolumn{2}{|c|}{ Detrending model } \\
\hline & Local spatial autocorrelation $^{1}$ & Range of spatial autocorrelation $(\mathrm{km})^{2}$ & Parameters $^{3}$ & $n$ \\
\hline Pinyon/juniper & 0.33 & $1,302.7$ & All & 16,709 \\
\hline Douglas-fir & 0.45 & 260.2 & All & 7,077 \\
\hline Oak/pine & 0.21 & 490.0 & All & 19,023 \\
\hline Oak/gum/cypress & 0.16 & 597.4 & All & 28,431 \\
\hline Elm/ash/cottonwood & 0.51 & 617.5 & All & 11,742 \\
\hline Aspen/birch & 0.13 & 536.6 & All & 46,411 \\
\hline Southern pine & 0.19 & 617.0 & All & 102,844 \\
\hline Oak/hickory & 0.14 & 524.0 & $x, y, x^{2}, y^{2}$ & 141,062 \\
\hline Maple/beech/birch & NS & NS & NS & 47,350 \\
\hline Tropical and exotic hardwoods & 0.35 & 404.6 & All & 408 \\
\hline Northern pines & 0.08 & 219.7 & $x, y, x^{2}, y^{2}$ & 9,151 \\
\hline Spruce/fir and exotic softwoods & NS & NS & NS & 18,761 \\
\hline Western conifers & 0.39 & 973.2 & $x, x y, y^{2}$ & 21,792 \\
\hline Western hardwoods & 0.65 & $1,167.8$ & $x, x^{2}, y^{2}$ & 1,924 \\
\hline Western oak & 0.37 & 990.7 & $x, y, x y, y^{2}$ & 3,207 \\
\hline
\end{tabular}

${ }^{1}$ Empirical mean (from 200 bootstrapped simulations) of the estimate of local autocorrelation as the distance between sampling locations approaches 0

${ }^{2}$ Mean distance (from 200 bootstrapped simulations) of the lag distance at which the estimate of local autocorrelation $=0$

${ }^{3}$ Full model parameters $=x, y, x y, x^{2}$, and $y^{2}$

NS not significant

value in Eq. 4 (Table 4). For these 13 forest types, we then obtained the detrended residuals from Eq. 4. To ensure that the second-order polynomial spatial model adequately removed the spatial autocorrelation, we then estimated the spatial autocorrelation of the residuals obtained from Eq. 4 for these 13 forest types using the bootstrap sampling approach described above. In all forest type cases, there was no significant local spatial autocorrelation in the residuals based upon the $95 \%$ confidence intervals. Thus, the spatially-detrended residuals for these 13 forest types were used in all follow-up analyses. For the remaining two forest types that did not exhibit significant spatial autocorrelation (maple/beech/ birch, and spruce/fir and exotic softwoods, Table 4), we used values of $C$ in all follow-up analyses. All analyses were conducted in R 2.14.0.

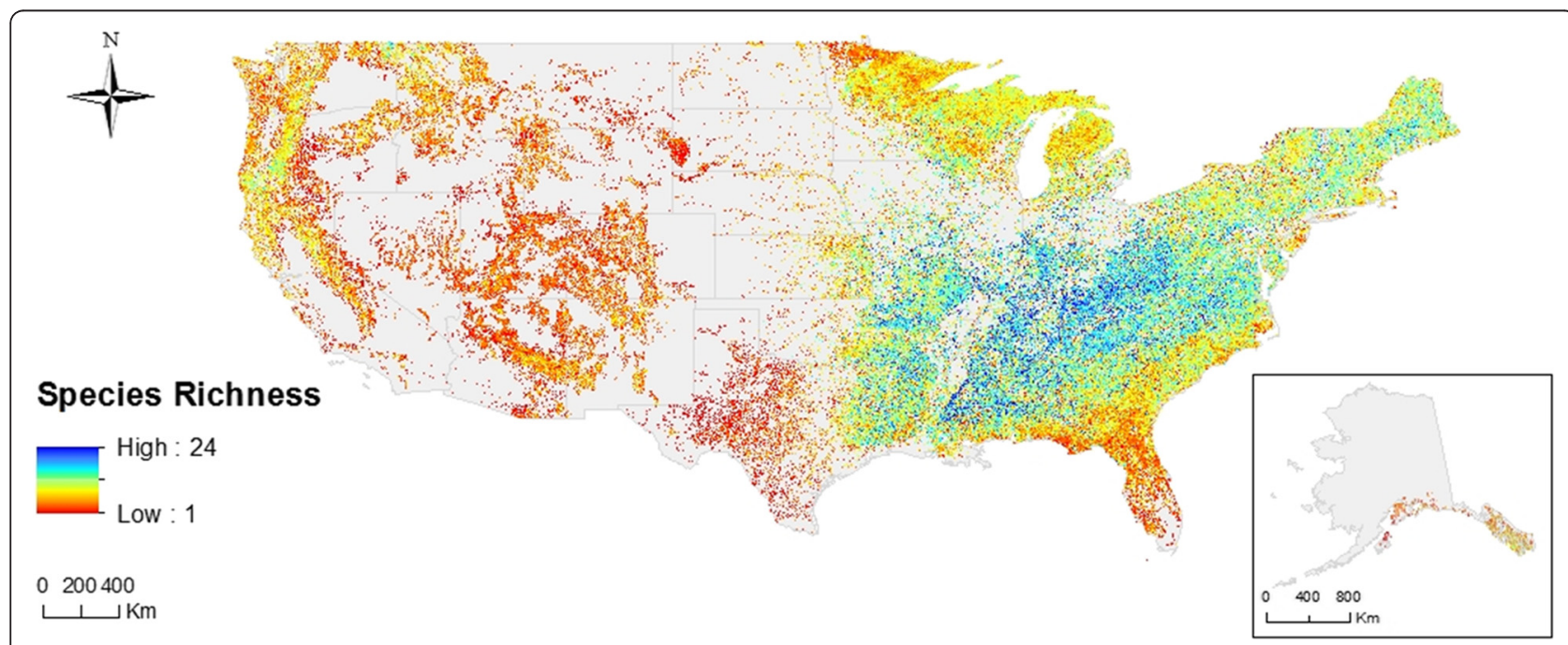

Fig. 3 Richness of woody plant species across the 48 contiguous U.S. states and Alaska, derived from FIA ground measurements completed between 1968 and 2011 


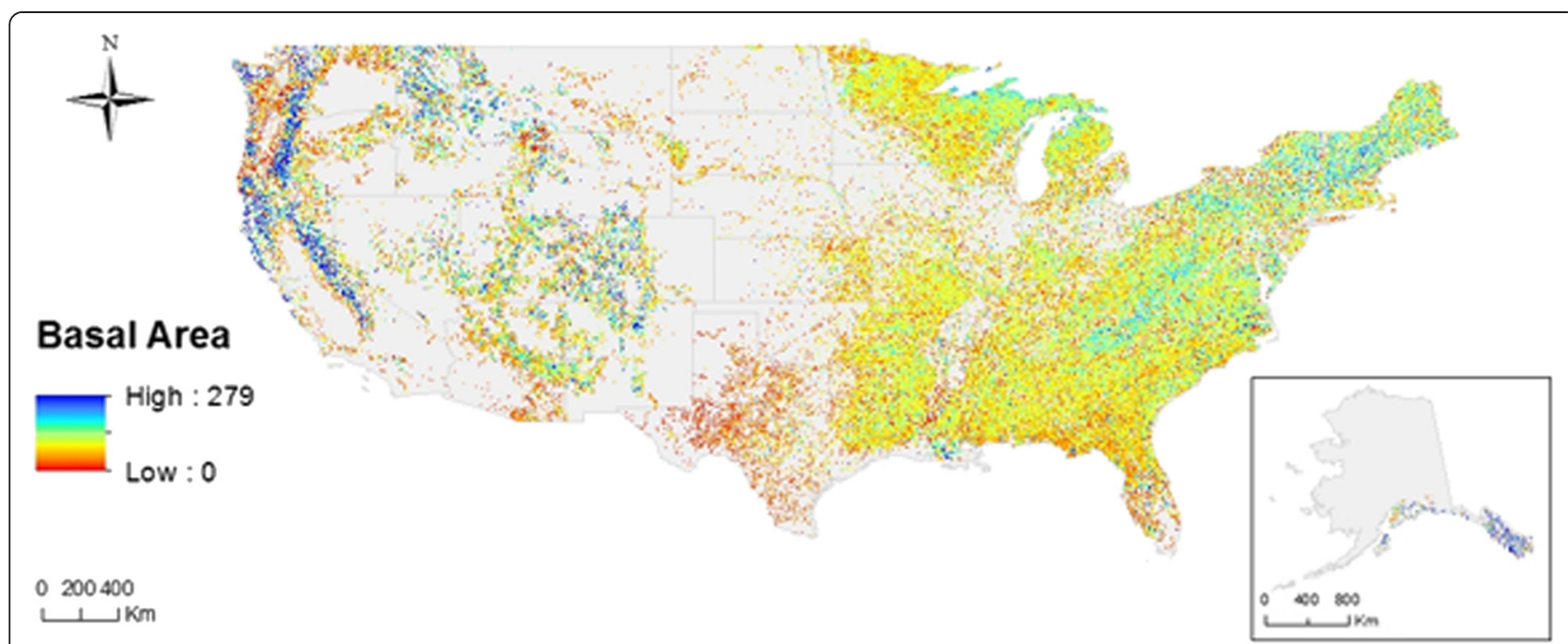

Fig. 4 Total forest stand basal area $\left(\mathrm{m}^{2} \cdot \mathrm{ha}^{-1}\right)$ across the 48 contiguous U.S. states and Alaska, derived from FIA ground measurements completed between 1968 and 2011

\section{Results}

\section{Geographic distribution of tree species richness, forest productivity and stocking}

The southeastern region (with an exception of the Gulf and Atlantic Coastal plains) and the Appalachian Mountains showed the highest tree species richness, whereas the majority of the mountainous regions of the western United States, the black hills region of South Dakota, western Texas, northwestern Minnesota, and the state of Florida had the lowest tree species richness (Fig. 3). In general, forests in the eastern United States consisted of more tree species than those in the central and western parts of the country including the state of Alaska. Over the contiguous United States, the highest forest stocking values were concentrated in the western United States and Central Appalachia (Fig. 4).

Forests with high site productivity were generally distributed in the western slopes of the mountain ranges in northern and central California, western Oregon and Washington, northern Idaho, the southeastern United States (except Florida), southern Michigan, and the states of Illinois and Indiana. The areas with the most notable overall low values of site productivity were the southern Rocky Mountains and western Texas (Fig. 5).

Oak/hickory and southern pine forests had the overall highest levels of species richness, and the western hardwoods, western conifers and western oak forests had the lowest (Table 2). The mean productivity over all of

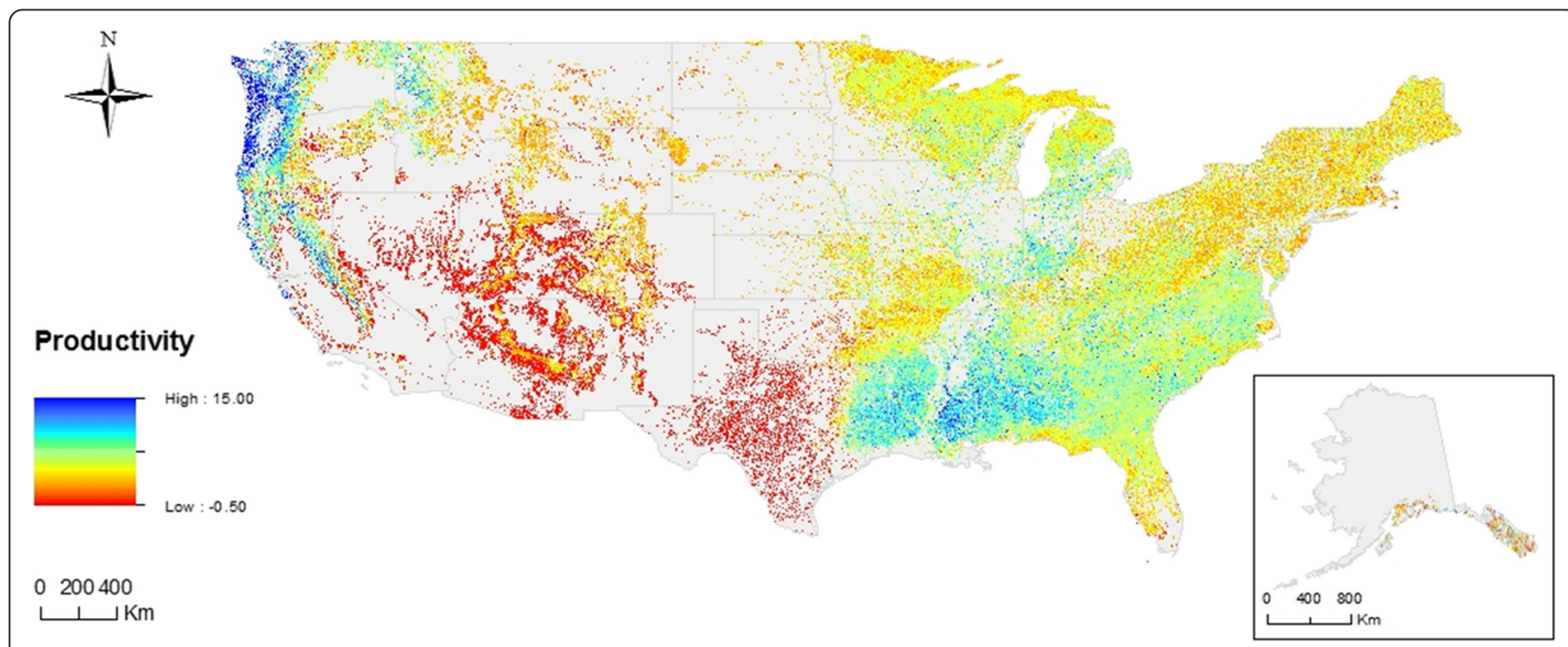

Fig. 5 Forest productivity $\left(\mathrm{m}^{3} \cdot \mathrm{ha}^{-1} \cdot \mathrm{yr}^{-1}\right)$ across the 48 contiguous U.S. states and Alaska, derived from FIA ground measurements completed between 1968 and 2011 
the forest types studied here was $4.84 \mathrm{~m}^{3} \cdot \mathrm{ha}^{-1} \cdot \mathrm{yr}^{-1}$. The most productive forest type was oak/gum/cypress whereas the least productive was pinyon/juniper. Average species richness for all forest types combined is 6.00 with a standard deviation of 3.42 (Table 2).

\section{Diversity-productivity relationship}

Throughout all the 15 forest types in the United States, 12 plus the interior Douglas-fir subtype showed a positive relationship between species richness and site productivity, and only the coastal Douglas-fir subtype, northern pines, tropical and exotic hardwoods, and western hardwoods forest types had a negative or insignificant relationship (Table 5). Species richness was highly significant for all but the tropical and exotic hardwoods forest type. Over all the study areas, $96.4 \%$ of sample plots $(477,281)$ conformed to a positive effect of species richness on site productivity, and only $3.6 \%(17,349)$ showed an insignificant or negative effect.

Based on the estimated coefficients of Eq. 3, when $B$ was kept constant at its sample mean, as species richness increased from 1 to the 75 th percentile values, site productivity was expected to increase by $1.2 \mathrm{~m}^{3} \cdot \mathrm{ha}^{-1} \cdot \mathrm{yr}^{-1}$ for the pinyon/juniper forest type, $4.0 \mathrm{~m}^{3} \cdot \mathrm{ha}^{-1} \cdot \mathrm{yr}^{-1}$ for the interior Douglas-fir subtype, $1.0 \mathrm{~m}^{3} \cdot \mathrm{ha}^{-1} \cdot \mathrm{yr}^{-1}$ for the oak/pine forest type, $1.6 \mathrm{~m}^{3} \cdot \mathrm{ha}^{-1} \cdot \mathrm{yr}^{-1}$ for the oak/ gum/cypress forest type, $0.3 \mathrm{~m}^{3} \cdot \mathrm{ha}^{-1} \cdot \mathrm{yr}^{-1}$ for the elm/ ash/cottonwood forest type, $1.0 \mathrm{~m}^{3} \cdot \mathrm{ha}^{-1} \cdot \mathrm{yr}^{-1}$ for the aspen/birch forest type, $1.8 \mathrm{~m}^{3} \cdot \mathrm{ha}^{-1} \cdot \mathrm{yr}^{-1}$ for the western oak forest type, $0.9 \mathrm{~m}^{3} \cdot \mathrm{ha}^{-1} \cdot \mathrm{yr}^{-1}$ for the southern pine forest type, $1.6 \mathrm{~m}^{3} \cdot \mathrm{ha}^{-1} \cdot \mathrm{yr}^{-1}$ for the spruce/fir and exotic softwoods forest type, $0.6 \mathrm{~m}^{3} \cdot \mathrm{ha}^{-1} \mathrm{yr}^{-1}$ for the oak/hickory forest type, and $1.5 \mathrm{~m}^{3} \cdot \mathrm{ha}^{-1} \cdot \mathrm{yr}^{-1}$ for the western conifers forest type (Fig. 6). The forests that showed a flat or negative diversity-productivity relationship were the coastal Douglas-fir subtype with a decline of $-1.0 \mathrm{~m}^{3} \cdot \mathrm{ha}^{-1} \cdot \mathrm{yr}^{-1}$, the northern pines forest type (flat), the tropical and exotic hardwoods forest type (flat), and the western hardwoods forest type with a decline of $-1.5 \mathrm{~m}^{3} \cdot \mathrm{ha}^{-1} \cdot \mathrm{yr}^{-1}$ (Fig. 6).

The FMPI data from Northeastern China conformed to the positive diversity-productivity relationship (Table 5). As species richness increased from 1 to 12 , productivity of the northeastern temperate forests in China improved from 2.5 to $4.0 \mathrm{~m}^{3} \cdot \mathrm{ha}^{-1} \cdot \mathrm{yr}^{-1}$, a $60 \%$ increase from the base value (Fig. 7).

\section{Discussion}

The findings largely support, from the perspectives of forested ecosystems over a large geographic scale, a positive biodiversity-ecosystem functioning relationship (BEFR). This is consistent with other experiments based generally on controlled field experiments with herbaceous species (see Cardinale et al. 2012 and references therein). Evidence from this study was unique because it was based upon almost half a million ground-measured forest inventory plots from a large geographic scale. Recognizing that different forest types vary in regards to

Table 5 Parameters of site productivity models by forest type with predictor variables of species richness, basal area, elevation, and slope

\begin{tabular}{|c|c|c|c|c|c|c|c|c|c|c|c|c|c|}
\hline \multirow[t]{2}{*}{ Forest type } & \multirow[t]{2}{*}{$n$} & \multirow[t]{2}{*}{$A / C$} & \multirow[t]{2}{*}{$B / C$} & \multicolumn{10}{|c|}{ Coefficients } \\
\hline & & & & Const. & & $N$ & & $N^{2}$ & & $N \cdot B$ & & $B$ & \\
\hline Pinyon/juniper & 16,709 & 47112 & 47158 & -0.398 & $* * *$ & 0.209 & $* * *$ & -0.012 & $* * *$ & 0.005 & $* * *$ & -0.010 & $* * *$ \\
\hline Douglas-fir (Coastal) & 5,866 & 29214 & 29241 & -0.024 & & & & -0.011 & $* * *$ & 0.002 & $* * *$ & & \\
\hline Douglas-fir (Interior) & 1,211 & 5259 & 5284 & -2.735 & $* * *$ & 0.809 & $* * *$ & -0.035 & $* *$ & & & 0.031 & $* *$ \\
\hline Oak/pine & 19,023 & 86805 & 86853 & -1.599 & $* * *$ & 0.205 & $* * *$ & -0.008 & $* * *$ & -0.001 & $*$ & 0.047 & $* *$ \\
\hline Oak/gum/cypress & 28,431 & 128225 & 128266 & -1.058 & $* * *$ & 0.142 & $* * *$ & & & -0.002 & $* * *$ & 0.019 & $* * *$ \\
\hline Elm/ash/cottonwood & 11,742 & 55755 & 55800 & -1.394 & $* * *$ & 0.244 & $* * *$ & -0.010 & $* * *$ & -0.003 & $* * *$ & 0.048 & $* *$ \\
\hline Aspen/birch & 46,411 & 200909 & 200953 & -0.865 & $* * *$ & 0.105 & $* * *$ & & & -0.004 & $* * *$ & 0.040 & $* *$ \\
\hline Southern pine & 102,844 & 457216 & 457273 & -1.070 & $* * *$ & 0.093 & $* * *$ & -0.001 & $* *$ & -0.001 & $* * *$ & 0.040 & $* *$ \\
\hline Oak/hickory & 141,062 & 636358 & 636397 & -0.798 & $* * *$ & 0.040 & $* * *$ & & & & & 0.026 & ** \\
\hline Maple/beech/birch & 47,350 & 206442 & 206495 & 3.703 & $* * *$ & -0.033 & * & 0.013 & $* * *$ & -0.004 & $* * *$ & 0.024 & $* *$ \\
\hline Tropical and exotic hardwoods & 408 & 1700 & 1712 & -0.409 & $* *$ & & & & & & & 0.028 & $* *$ \\
\hline Northern pines & 9,151 & 40244 & 40280 & -1.469 & $* * *$ & 0.161 & $* * *$ & & & -0.007 & $* * *$ & 0.075 & $* *$ \\
\hline Spruce/fir and exotic softwoods & 18,761 & 79280 & 79327 & 2.011 & $* * *$ & 0.479 & $* * *$ & -0.025 & $* * *$ & -0.002 & $* *$ & 0.008 & * \\
\hline Western conifers & 21,792 & 101207 & 101247 & -1.409 & $* * *$ & 0.184 & $* * *$ & & & 0.003 & $* * *$ & 0.029 & $* *$ \\
\hline Western hardwoods & 1,924 & 8041 & 8075 & -0.386 & $* *$ & 0.446 & $* *$ & -0.125 & $* * *$ & 0.010 & $* * *$ & -0.017 & * \\
\hline Western oak & 3,207 & 15060 & 15090 & -1.311 & $* * *$ & 0.409 & $* * *$ & -0.037 & * & 0.015 & $* * *$ & & \\
\hline Chinese northeastern temperate forest & 1,385 & 4768 & 4789 & 1.288 & $* * *$ & 0.397 & $* * *$ & -0.017 & $* * *$ & -0.0007 & & 0.004 & \\
\hline
\end{tabular}




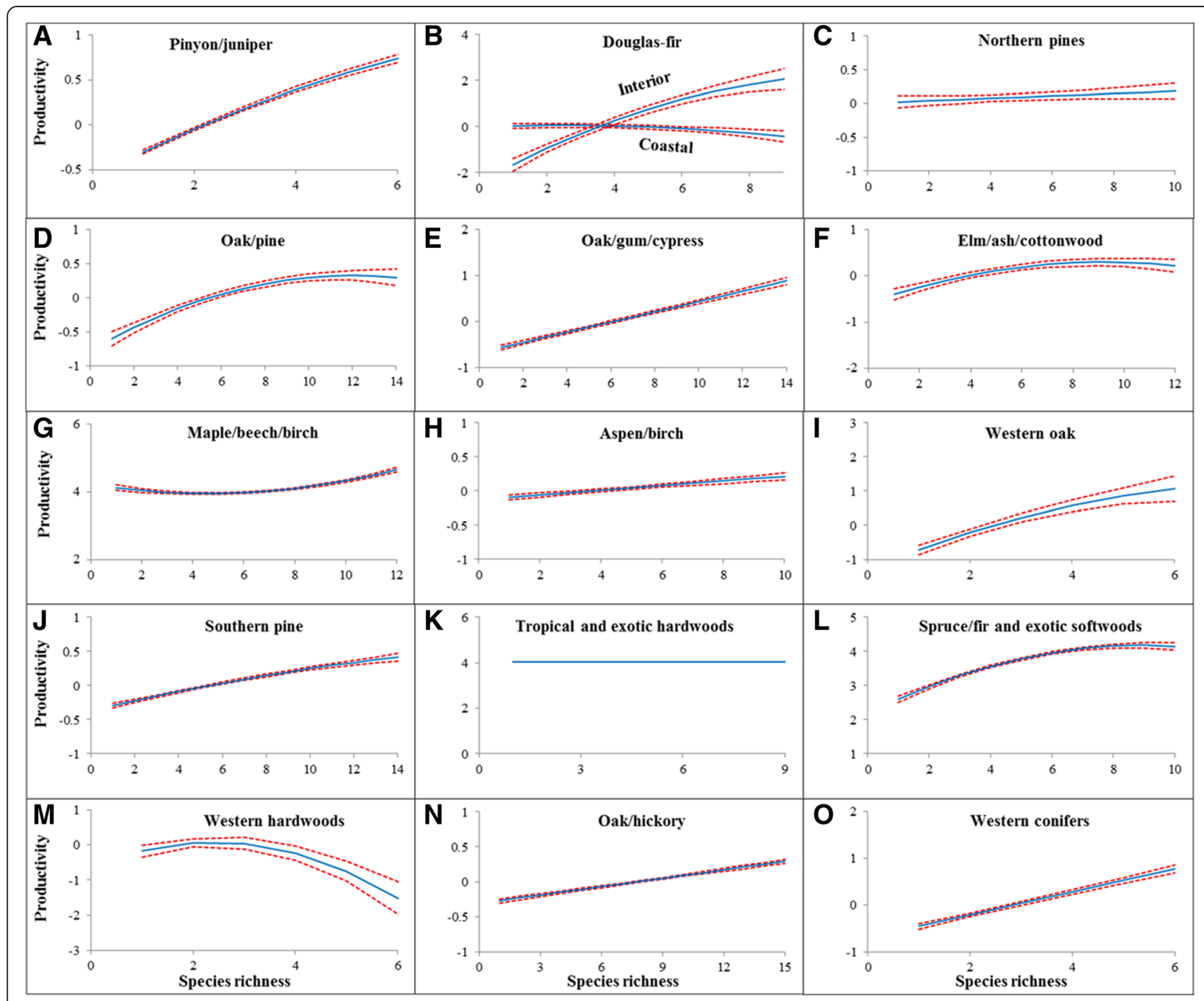

Fig. 6 Sensitivity of stand productivity $\left(\mathrm{m}^{3} \cdot \mathrm{ha}^{-1} \cdot \mathrm{yr}^{-1}\right)$ to species richness for 15 forest types (each panel represents one type of forest) across the 48 contiguous U.S. states and Alaska. Solid lines represent predicted means of different forest types and broken lines the $95 \%$ confidence interval of the predicted means, with stand basal area being kept constant at its sample mean

how species diversity affects productivity, we categorized all the ground-measured plots into 15 forest types, and analyzed the diversity-productivity relationship specific to each forest type. The number of ground-measured plots, as well as the magnitude of geographic scale, rendered overwhelming evidence in support of a positive tree species diversity-timber productivity relationship.

The negative diversity productivity relationship for the coastal Douglas-fir subtype that was found (Fig. 6b) contradicts with the positive net basal area change in association with tree species diversity reported by Liang et al. (2007) for the same subtype. The main reason for this discrepancy may be in the measure of site productivity. While Liang et al. (2007) measured site productivity by net annual basal area change, which represents actual forest growth, this study quantified site productivity as potential timber growth that a site could sustain. Our results indicate that intensively managed coastal Douglas-fir forests feature a negative effect of diversity on potential timber growth presumably because these stands are artificially maintained in an early stage of stand development (stem exclusion) where current annual increment is nearly optimized at a low diversity. The inland Douglas-fir forests conformed to the positive biodiversity-forest productivity relationship as they are less intensively managed. It should be noted, however, that this implication was only applicable to Douglas-fir forests, which are in general low in tree species diversity. Southern pine forests, in spite of high management intensity, still show a positive tree species diversity-timber productivity relationship (Fig. 6j). A 


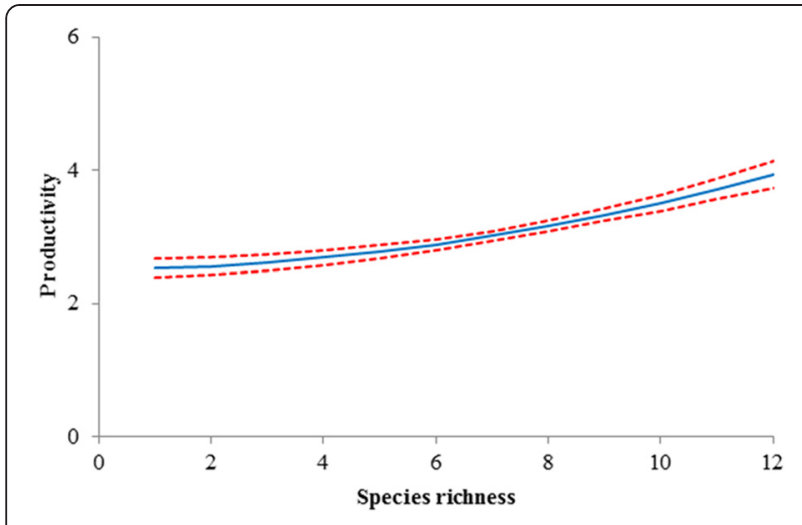

Fig. 7 Sensitivity of stand productivity $\left(\mathrm{m}^{3} \cdot \mathrm{ha}^{-1} \cdot \mathrm{yr}^{-1}\right)$ to species richness for the northeastern temperate forests in China. Solid lines represent predicted means of different forest types and broken lines the $95 \%$ confidence interval of the predicted means, with stand basal area being kept constant at its sample mean

possible explanation is southern pine forests by nature consist of more tree species than Douglas-fir forests. Also, the niche complementarity effect (see Loreau and Hector 2001 and references therein) that contributes to the positive BEFR could therefore be more prominent in the southern pine forests.

Due to the use of observational data, the observed trends are subject to the usual caveats of multicollinearity. However, multicollinearity does not lead to a biased diversity-productivity relationship (Goldberger 1991), even though it may lead to difficulties in quantifying the variance of predicted means. The partial effects of diversity may be more uncertain due to multicollinearity. Nevertheless, multicollinearity was not excessive in the present case as the Variance Inflation Factor of tree species richness $(N)$ was estimated to be 1.08 using the "car" package of R (Fox and Weisberg 2011), and all the forest types show very low standard errors in predicted site productivity (Fig. 6). Another statistical caveat of this study, due to the use of observational data, is in the causal relationship between diversity and productivity. Without a controlled experiment, it is difficult to determine the cause and effect in the diversity-productivity relationship. Compared to controlled experiments, this empirical evidence provides insights to forest management and biological conservation that are of a much broader applicability, both in terms of forest type and geographic scale.

The fuzzed FIA plot coordinates could affect the accuracy of the estimated site productivity $(C)$, as $70 \%$ of plot elevation records and $6 \%$ of plot slope records were obtained from a DEM using the fuzzed coordinates. Nevertheless, the impact should be small, as the differences between fuzzed coordinates and true locations of
FIA plots can be treated as a normally distributed random process. Furthermore, as most forests across the United States are distributed on relatively flat surfaces, bias in elevation that is caused by fuzzed coordinates was limited. Slope data is the most sensitive to plot locations, but the accuracy of the site productivity model was maintained as $94 \%$ of the data were measured in the field and only $6 \%$ were estimated using the fuzzed coordinates.

\section{Conclusion}

Over all the study areas, 96.4 percent of sample plots $(477,281)$ showed a positive effect of species richness on site productivity, and only 3.6 percent $(17,349)$ had an insignificant or negative effect.

The results of this study suggest that maintaining species diversity is an important means to maintain forest productivity, which is supported by an array of forestry studies (Kelty 1989; Caspersen and Pacala 2001; Liang et al. 2005, 2007; Lei et al. 2009b; Young et al. 2011; Zhang et al. 2012; Gamfeldt et al. 2013). These results should assist landowners in making management decisions that are relevant to the specific forest types that they respectively manage. These findings also imply that productivity of forests across the United States may be impaired by the loss of both woody and non-woody plant species in forested ecosystems (Fleming et al. 2011; Liang et al. 2015), and that biological conservation, due to its potential benefits in maintaining forest productivity, can have profound impacts on the productivity of selected services that can be obtained from forests across the United States.

\section{Competing interests}

The authors declare that they have no competing interests.

\section{Authors' contributions}

$J \mathrm{WW}, J \mathrm{~L}$, and $\mathrm{XL}$ compiled the data. JWW, JL, and CEA conducted mapping. $J \mathrm{WW}, J \mathrm{~L}$, and PCT performed regression analysis. All authors contributed to the writing, and read and approved the final manuscript.

\section{Acknowledgements}

We are obliged to Karen Waddell and Charles J. Barnett for assistance with FIA data. We thank Mo Zhou, Jacquelyn Strager, George Merovich, and Eric King for statistical and mapping assistance. This research is supported in parts by the United States Department of Agriculture McIntire-Stennis Act Fund WVA00104, and by the Division of Forestry and Natural Resources, West Virginia University.

\section{Author details}

${ }^{1}$ Davis College of Agriculture, Natural Resources and Design, West Virginia University, 26506 Morgantown, WV, USA. ${ }^{2}$ Forest Service, U.S. Department of Agriculture, Northern Research Station, 26505 Morgantown, WV, USA. ${ }^{3}$ School of Environmental and Forest Sciences, University of Washington, 98195 Seattle, WA, USA. ${ }^{4}$ Research Institute of Forest Resource Information Techniques, Chinese Academy of Forestry, 100091 Beijing, P. R. China. 


\section{References}

Assmann E (1970) The principles of forest yield study. Pergamon Press, Oxford, UK Bechtold WA, Scott CT (2005) The forest inventory and analysis plot design. In: the enhanced forest inventory and analysis program: national sampling design and estimation procedures. USDA Forest Service, Asheville, NC, pp 27-42

Bjørnstad ON, Falck W (2001) Nonparametric spatial covariance functions: estimation and testing. Environ Ecol Stat 8:53-70

Buongiorno J, Peyron JL, Houllier F, Bruciamacchie M (1995) Growth and management of mixed-species, uneven-aged forests in the French Jura: implications for economic returns and tree diversity. For Sci 41:397-429

Cardinale BJ, Duffy JE, Gonzalez A, Hooper DU, Perrings C, Venail P, Narwani A, Mace GM, Tilman D, Wardle DA, Kinzig AP, Daily GC, Loreau M, Grace JB, Larigauderie A, Srivastava DS, Naeem S (2012) Biodiversity loss and its impact on humanity. Nature 486:59-67

Cardinale BJ, Matulich KL, Hooper DU, Byrnes JE, Duffy E, Gamfeldt L, Balvanera P, O'Connor MI, Gonzalez A (2011) The functional role of producer diversity in ecosystems. Am J Bot 98:572-592

Caspersen JP, Pacala SW (2001) Successional diversity and forest ecosystem function. Ecol Res 16:895-903

Chen HYH, Klinka K, Mathey AH, Wang X, Varga P, Chourmouzis C (2003) Are mixed-species stands more productive than single-species stands: an empirical test of three forest types in British Columbia and Alberta. Can J For Res 33:1227-1237

Clifford P, Richardson S, Hémon D (1989) Assessing the significance of the correlation between two spatial processes. Biometrics 45:123-134

Efron B, Tibshirani RJ (1993) An introduction to the bootstrap. Chapman \& Hall, New York

FAO (2012) State of the world's forests 2012. Food and Agriculture Organization of the United Nations, Rome, Italy, p 46

Fleming R, Brown N, Jenik J, Kahumbu P, Plesnik J (2011) Emerging perspectives on forest biodiversity. In: United Nations Environment Program (ed) UNEP year book 2011. UNEP, Nairobi, Kenya, pp 46-59

Fox J, Weisberg S (2011) An R companion to applied regression. Sage, Thousand Oaks, CA

Gamfeldt L, Snall T, Bagchi R, Jonsson M, Gustafsson L, Kjellander P, Ruiz-Jaen MC, Froberg M, Stendahl J, Philipson CD, Mikusinski G, Andersson E, Westerlund B, Andren H, Moberg F, Moen J, Bengtsson J (2013) Higher levels of multiple ecosystem services are found in forests with more tree species. Nat Commun 4:1340

Gillespie AJ (1999) Rationale for a national annual forest inventory program. J For 97:16-20

Goldberger AS (1991) A course in econometrics. Harvard University Press, Cambridge, MA

Haight RG, Monserud RA (1990) Optimizing any-aged management of mixed-species stands: II. Effects of decision criteria. For Sci 36:125-144

Hanson EJ, Azuma DL, Hiserote BA (2003) Site index equations and mean annual increment equations for Pacific Northwest Research Station forest inventory and analysis inventories, 1985-2001. U.S. Dept. of Agriculture, Forest Service, Pacific Northwest Research Station, Portland, OR

Hasse WD, Ek AR (1981) A simulated comparison of yields for even- versus uneven-aged management of northern hardwood stands. J Environ Manage 12:235-246

He P, Zhang H, Lei X, Li X (2013) Estimation of spatial distribution of tree species diversity based on Universal Krige Model. J Central-South Univ For Technol 33:67-71

Hermann RK, Lavender DP (1990) Douglas-fir. In: Burns RM, Honkala BH (eds) Silvics of North America. U.S. Department of Agriculture, Forest Service, Washington DC, pp 527-540

Hernández-Stefanoni JL, Dupuy JM (2007) Mapping species density of trees, shrubs and vines in a tropical forest, using field measurements, satellite multiespectral imagery and spatial interpolation. Biodivers Conserv 16:3817-3833

Hernandez-Stefanoni JL, Ponce-Hernandez R (2006) Mapping the spatial variability of plant diversity in a tropical forest: comparison of spatial interpolation methods. Environ Monit Assess 117:307-334

Hooper DU, Chapin FS, Ewel JJ, Hector A, Inchausti P, Lavorel S, Lawton JH, Lodge DM, Loreau M, Naeem S, Schmid B, Setala H, Symstad AJ, Vandermeer J, Wardle DA (2005) Effects of biodiversity on ecosystem functioning: a consensus of current knowledge. Ecol Monogr 75:3-35

Hooper DU, Vitousek PM (1997) The effects of plant composition and diversity on ecosystem processes. Science 277:1302-1305
Kelty MJ (1989) Productivity of New England hemlock/hardwood stands as affected by species composition and canopy structure. For Ecol Manage 28:237-257

Köble R, Seufert G (2001) Novel maps for forest tree species in Europe. In: Hjorth J, Raes F, Angeletti G (eds) Proceedings of the 8th European symposium on the physico-chemical behaviour of air pollutants: a changing atmosphere. Commission of the European Communities, Directorate Genera Telecommunications, Information Industries and Innovation. Torino, Italy, pp 17-20

Kreft H, Jetz W (2007) Global patterns and determinants of vascular plant diversity. Proc Natl Acad Sci U S A 104:5925-5930

Legendre P (1993) Spatial autocorrelation: trouble or new paradigm? Ecology 74:1659-1673

Lei X, Tang M, Lu Y, Hong L, Tian D (2009a) Forest inventory in China: status and challenges. Int For Rev 11:52-63

Lei X, Wang W, Peng C (2009b) Relationships between stand growth and structural diversity in spruce-dominated forests in New Brunswick, Canada. Can J For Res 39:1835-1847

Leuschner C, Jungkunst HF, Fleck S (2009) Functional role of forest diversity: pros and cons of synthetic stands and across-site comparisons in established forests. Basic Appl Ecol 10:1-9

Liang J (2012) Mapping large-scale forest dynamics: a geospatial approach. Landscape Ecol 27:1091-1108

Liang J, Buongiorno J, Monserud RA (2005) Growth and yield of all-aged Douglas-fir/western hemlock stands: a Matrix model with stand diversity effects. Can J For Res 35:2369-2382

Liang J, Buongiorno J, Monserud RA (2006) Bootstrap simulation and response surface optimization of management regimes for Douglas-fir/western hemlock stands. For Sci 52:579-594

Liang J, Buongiorno J, Monserud RA, Kruger EL, Zhou M (2007) Effects of diversity of tree species and size on forest basal area growth, recruitment, and mortality. For Ecol Manage 243:116-127

Liang J, Zhou M, Tobin PC, McGuire AD, Reich PB (2015) Biodiversity influences plant productivity through niche-efficiency. Proc Natl Acad Sci U S A 112:5738-5743

Lister A, Scott C, King S, Hoppus M, Butler B, Griffith D (2002) Strategies for preserving owner privacy in the national information management system of the USDA Forest Service's forest inventory and analysis unit. In: McRoberts RE (ed) The fourth annual forest inventory and analysis symposium. USDA Forest Service, New Orleans, LA, pp 163-166

Loreau M, Hector A (2001) Partitioning selection and complementarity in biodiversity experiments. Nature 412:72-76

Loreau M, Naeem S, Inchausti P, Bengtsson J, Grime JP, Hector A, Hooper DU, Huston MA, Raffaelli D, Schmid B, Tilman D, Wardle DA (2001) Biodiversity and ecosystem functioning: current knowledge and future challenges. Science 294:804-808

Naeem S, Duffy JE, Zavaleta E (2012) The functions of biological diversity in an age of extinction. Science 336:1401-1406

Paquette A, Messier C (2011) The effect of biodiversity on tree productivity: from temperate to boreal forests. Global Ecol Biogeogr 20:170-180

Reich PB, Tilman D, Isbell F, Mueller K, Hobbie SE, Flynn DFB, Eisenhauer N (2012) Impacts of biodiversity loss escalate through time as redundancy fades. Science 336:589-592

Ricketts TH (1999) Terrestrial ecoregions of North America: a conservation assessment. Island Press, Washington, DC

Ruefenacht B, Finco MV, Nelson MD, Czaplewski R, Helmer EH, Blackard JA, Holden GR, Lister AJ, Salajanu D, Weyermann D, Winterberger K (2008) Conterminous US and Alaska forest type mapping using forest inventory and analysis data Photogramm. Eng Remote Sensing 74:1379-1388

Shugart HH (1984) A theory of forest dynamics: the ecological implications of forest succession models. Springer Verlag, New York

Stage AR, Salas C (2007) Interaction of elevation, aspect, and slope in models of forest species composition and productivity. For Sci 53:486-492

Symstad AJ, Chapin FS, Wall DH, Gross KL, Huenneke LF, Mittelbach GG, Peters DP, Tilman D (2003) Long-term and large-scale perspectives on the relationship between biodiversity and ecosystem functioning. Bioscience 53:89-98

Vilà M, Vayreda J, Gracia C, Ibáñez JJ (2003) Does tree diversity increase wood production in pine forests? Oecologia 135:299-303

Wardle DA (1999) Is "sampling effect" a problem for experiments investigating biodiversity-ecosystem function relationships? Oikos 87:403-407

Wooldridge JM (2000) Introductory econometrics: a modern approach. South-Western College Publishing, Cincinnati, $\mathrm{OH}$ 
Woudenberg S, Conkling B, O'Connell B, LaPoint E, Turner J, Waddell K, Boyer D, Christensen G, Ridley T (2011) The forest inventory and analysis database: description and users manual version 51 for phase 2. US Department of Agriculture, Forest Service, Fort Collins, CO, p 336

Young B, Liang J, Stuart Chapin F III (2011) Effects of species and tree size diversity on recruitment in the Alaskan boreal forest: a geospatial approach. For Ecol Manage 262:1608-1617

Zhang Y, Chen HYH, Reich PB (2012) Forest productivity increases with evenness, species richness and trait variation: a global meta-analysis. J Ecol 100:742-749

Submit your manuscript to a SpringerOpen ${ }^{\circ}$ journal and benefit from:

- Convenient online submission

- Rigorous peer review

- Immediate publication on acceptance

- Open access: articles freely available online

- High visibility within the field

- Retaining the copyright to your article

Submit your next manuscript at $\gg$ springeropen.com 